\title{
COVID-19 in Children
}

\section{COVID-19 kod djece}

\author{
Diana Didović1, Andrea Nikčević1, Ivana Valenčak-Ignjatić1, Lorna Stemberger Marić1 ${ }^{12}$, Srđan Roglić1 ${ }^{1,2}$ \\ ${ }^{1}$ Pediatric Infectious Diseases Department, University Hospital for Infectious Diseases "Dr. Fran Mihaljević", Zagreb, Croatia \\ ${ }^{2}$ School of Medicine, University of Zagreb, Zagreb, Croatia
}

Keywords:
SARS-CoV-2
children
COVID-19
multisystem inflammatory syndrome in children (MIS-C)
paediatric multisystem inflammatory syndrome

Ključne riječi:
SARS-CoV-2
djeca
COVID-19
multisistemski upalni indrom kod djece (MIS-C)
pedijatrijski multisistemski inflamatorni sindrom

Primljeno: 01-11-2020

Received: 01-11-2020

Prihvaćeno: $02-12-2020$

Accepted: 02-12-2020

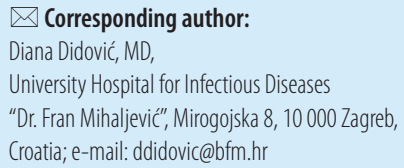

\section{Introduction}

Although individuals of all ages are susceptible to SARS-CoV-2 infection, children account for only 1 to $8 \%$ of all laboratory-confirmed cases..$^{[1,2]}$ Also, children have largely been identified through contact tracing of infected adults in households and COVID-19 appears to be milder in children. ${ }^{[3,4]}$ This could be explained with higher levels of antibodies against virus in children than in adults as a result of repeated viral respiratory infections or the children could be less sensitive to SARS-CoV-2 infection because the maturity and bind-

\begin{abstract}
COVID-19 in children accounts for up to $8 \%$ of all the cases and is less severe than in adults. This could be an underestimation. A significant number of children are asymptomatic. Symptomatic infection is hard to distinguish from other respiratory tract viral infections based on symptoms and laboratory results. Anosmia is the only symptom in children that is highly suggestive of COVID-19. Infected children mostly have a positive household member. However, the role of children in SARS-CoV-2 transmission is still controversial. Data suggest that schoolchildren have a greater impact in SARS-CoV-2 transmission compared to younger children. Multisystem inflammatory syndrome in children is a new entity reported since April 2020 and is considered a rare complication of SARS-CoV-2 infection. It occurs in previously healthy older children and adolescents presenting with multisystem involvement and elevated inflammatory markers. 政 children respond well to immune-modifying therapy.

tment of COVID-19 in children is based solely on data received from adults and consists of supportive treatment d, in rare occasions, antiviral therapy (remdesivir), corticosteroids (dexamethasone) and monoclonal antibodies (tocilizumab). Further studies in children are needed in order to better understand this disease. This article discusses clinical presentation and therapeutic options for COVID-19 in children.
\end{abstract}

\section{Sažetak}

Gotovo 8\% svih slučajeva COVID-19 javlja se u dječjoj dobi, a klinička je slika blaža u odnosu na odrasle bolesnike. Ovaj je postotak vjerojatno I veći, s obzirom na činjenicu da velik broj djece ne pokazuje simptome bolesti. Na temelju simptoma i laboratorijskih nalaza, simptomatsku je infekciju teško razlikovati od ostalih virusnih respiratornih infekcija. Jedini simptom koji je vrlo sugestivan za COVID-19 kod djece je anosmija. Djeca oboljela od COVID-19 najčešće imaju pozitivan kontakt u kućanstvu, ali je uloga djece u transmisiji SARS-CoV-2 još uvijek kontroverzna. Djeca školske dobi imaju veću ulogu u transmisiji SARS-CoV-2 od mlađe djece. Multisistemski hiperinflamatorni sindrom kod djece rijetka je posljedica SARS-CoV-2 infekcije i razvija se kod prethodno zdrave djece i adolescenata, a karakteriziran je zahvaćanjem više organskih sustava i povišenim upalnim parametrima. Većina djece ima zadovoljavajući klinički odgovor na imunomodulatornu terapiju.

Preporuke za liječenje COVID-19 kod djece oslanjaju se na preporuke o liječenju odraslih, a sastoje se od suportivnog liječenja te, u rijetkim slučajevima, antivirusne terapije (remdesivir), kortikosteroida (deksametazon) monoklonskih protutijela (tocilizumab). Potrebne su daljnje studije u svrhu boljeg razumijevanja ove bolesti. U ovom članku raspravljamo o kliničkoj prezentaciji i liječenju COVID-19 kod djece. ing ability of angiotensin-converting enzyme (ACE2) in children may be lower than that in adults. ${ }^{[5]}$ Nevertheless, $2.5 \%$ of infected children develop severe and $0.2 \%$ critical disease. $^{[3]}$

Due to relatively small number of infected children, reports on clinical presentation are scarce and treatment recommendations are almost solely based on data in adults. Another important issue that is still controversial is the role of the children in the transmission of SARS-CoV-2. ${ }^{[6]}$ 


\section{Coronaviruses}

Coronaviridae family contains large, enveloped, single stranded RNA viruses. ${ }^{[7]}$ The human coronaviruses $(\mathrm{HCoV})$ are 229E, NL63, HKU1, OC43, Middle East respiratory syndrome coronavirus (MERS-CoV) and severe acute respiratory syndrome coronavirus (SARS-CoV). Asymptomatic individuals of all ages periodically carry coronaviruses on respiratory tract mucosa. ${ }^{[7]}$ Four HCoVs (HCoV 229E, NL63, OC43, and HKU1) are endemic at a global level and account for $10 \%$ to $30 \%$ of the upper respiratory tract infections in adults. ${ }^{[8]} \mathrm{HCoVs}$ have been described as important viral causes of acute otitis media and otitis media with effusion in children. ${ }^{[9]}$ Although $\mathrm{HCoVs}$ have long been regarded inconsequential pathogens due to their mild clinical manifestations in humans, two large-scale epidemics with alarming morbidity and mortality in the early 21 st century - i.e., SARS and MERS - have changed that view.

On January 7th, 2020, the Chinese authorities identified a new type of coronavirus (novel coronavirus, $\mathrm{nCoV}$ ) which was officially announced on the following day as the causative pathogen of the outbreak in Huanan market by China CDC and was later renamed severe acute respiratory syndrome coronavirus (SARS-CoV-2). ${ }^{[10,11]}$

\section{Viral Shedding and Transmission}

The routes of SARS-CoV-2 transmission are direct person-to-person contact, mainly via respiratory droplets, indirectly via contaminated fomites and airborne microdroplets. The latter mechanism was the most likely mechanism explaining the spatial pattern of infections after the SARS-CoV- 1 epidemic and there is every reason to believe that SARS-CoV-2 behaves similarly. ${ }^{[12]}$ Droplets do not travel more than two meters (six feet). ${ }^{[7]}$ Several reports described that viral shedding from the gastrointestinal system lasts longer than the one from the respiratory tract suggesting that faecal-oral transmission may be possible. ${ }^{[4,13]}$ However, faecal-oral transmission has not been clinically described and it does not seem to play a role in the spread of disease. ${ }^{[3]}$ SARS-CoV-2 has also been detected in other non-respiratory specimens, including blood, ocular secretions, and semen, but the significance of these sites in transmission remains unclear.

SARS-CoV-2 is transmitted from infected persons, even during the incubation period, and from asymptomatic individuals. ${ }^{[14]} \mathrm{A}$ recent study analysed the viral load in nasal and throat swabs from symptomatic patients in relation to the first day of symptom onset. The viral loads peaked soon after illness onset and were higher in nose compared to throat. Also, a compara- ble viral load was detected in asymptomatic patients suggesting possible transmission from asymptomatic or paucisymptomatic patients. ${ }^{[15]}$

\section{The Role of Children in Transmission}

To what extent the children contribute to SARSCoV-2 transmission is still controversial. This issue is important because of significant public health repercussions, such as safe day care facilities and schools re-opening. A study by Contejean et al., which compared determinants and dynamics of SARS-CoV-2 transmission among 1344 health care workers (HCW), concluded that the contact with children attending out-of-home care facilities was not related with residual transmission. ${ }^{[16]}$

The children were the index cases in less than $10 \%$ of the family clusters. However, this data should be interpreted with caution since they were collected during the period of quarantine and physical distance measures in most countries. ${ }^{[2,17]}$

According to several articles, the children between 10 and 19 years of age (representing school-children) have a greater impact in SARS-CoV-2 transmission than younger children (0-9 years), i.e., in a study by Park et al., the transmission rate amounted to $18.6 \%$, compared to $5.3 \%$ during school closure. This study did not investigate the transmission dynamics (index patient and positive contact may have had a common exposure) ${ }^{[18]}$ A study from Israel showed significant increase in the proportion of school-age children among SARS-CoV-2 infected persons from $19.8 \%$ to $40.9 \%$ after schools reopening in May. The factors contributing to the infection spread included return of the teenage students to their regular classes and an extreme heat wave which has led to the exemption of facemasks and continuous air-conditioning usage. ${ }^{[19]}$ The symptomatic children shed virus in similar quantities to adults and can infect others in similar ways. Still, it is unknown to what extent the asymptomatic children are infectious. ${ }^{[20]}$

\section{Clinical Characteristics}

A study by Dong et al. showed that the children of all ages are susceptible to SARS-CoV-2, with no significant gender difference. The clinical manifestations in children are milder and the case fatality rate is much lower than in adults. The limitation of this study is that only 731 cases (34.1\%) were laboratory confirmed, while others were clinically diagnosed. The children were divided in five groups according to symptoms severity: $12.9 \%$ were asymptomatic (no symptoms, normal chest radiograph), $43.1 \%$ had mild symptoms (upper respiratory tract infection symptoms), 
$41.0 \%$ moderate symptoms (pneumonia, frequent fever, cough without obvious hypoxemia or lung lesions on chest CT in individuals with no clinical signs and symptoms), $2.5 \%$ were severely ill (oxygen saturation less than $92 \%$ with other hypoxia manifestations) and $0.4 \%$ of the children were critically ill (respiratory failure, shock, encephalopathy, myocardial injury or heart failure, coagulation dysfunction and acute kidney injury). ${ }^{[21]}$

Younger children, particularly infants, and those without laboratory confirmation were more likely to have severe disease than those with confirmed SARSCoV-2 infection, most probably due to infection with some other pathogen, notably RSV. A study by Song et al. showed no significant difference in the rates of hospitalization, admission to the intensive care unit, and mechanical ventilator use in children with COVID-19 and children with seasonal influenza. ${ }^{[22]}$

Among the laboratory confirmed cases, the most common symptom is pyrexia, present in up to $65 \%$ of the cases. ${ }^{[23]}$ Thus, absence of fever does not exclude the diagnosis. The signs and symptoms of upper and lower respiratory tract infection are present in 54\% and $25 \%$, respectively. The gastrointestinal symptoms are present in $22 \%$ and up to $16 \%$ of individuals are asymptomatic. ${ }^{[23]}$

Dyspnoea, cyanosis and respiratory insufficiency occur usually during the second week after the onset of symptoms. ${ }^{[14]}$ The disease can progress rapidly; severe respiratory failure, metabolic acidosis and irreversible bleeding and coagulation dysfunction may occur. ${ }^{[14]}$

The patients requiring intensive care support during hospitalization had coexisting conditions. This data suggests that there are subpopulations of children at increased risk for more significant illness, which is consistent with data on other coronaviruses. ${ }^{[2]} \mathrm{A}$ European multinational, multicentre cohort study, which included 582 patients, reported that significant risk factors for requiring ICU admission were age younger than 1 month, pre-existing medical conditions and presence of lower respiratory tract infection signs or symptoms at presentation. Altogether 145 patients (25\%) had pre-existing medical condition and accounted for $52 \%$ of the ICU admissions. ${ }^{[23]}$ The most common conditions were chronic pulmonary disease, malignancies, neurological disorders, congenital heart disease, chromosomal abnormalities and chronic kidney disease. ${ }^{[23]}$ Other studies with smaller sample size showed similar results.

Since clinical manifestation of SARS-CoV-2 infection in children overlap with those caused by other respiratory pathogens, it is extremely difficult to make diagnosis solely on the basis of symptoms and labo- ratory findings. ${ }^{[22]}$ Sudden olfactory loss is a highly specific symptom of COVID-19 in adults and is rarely accompanied by a severely blocked nose. ${ }^{[25]}$ ) Children also report anosmia, but not as often as adults. ${ }^{[26,27]}$ However, it is the only symptom in children that is highly suggestive of COVID-19.

In April 2020, there were first reports from the United Kingdom of a cluster of children presenting similar to incomplete Kawasaki disease (KD) or toxic shock syndrome and since then, similar cases have been reported in other parts of the world. ${ }^{[28]}$ This syndrome has been termed multisystem inflammatory syndrome in children (MIS-C) and is also referred to as paediatric multisystem inflammatory syndrome, paediatric hyperinflammatory syndrome or paediatric hyperinflammatory shock. Incidence of MIS-C is still unknown but appears to be a rare complication. Most children meet criteria for complete or incomplete KD but the epidemiology differs from classic KD because MIS-C occurs in previously healthy older children and adolescents, whereas $\mathrm{KD}$ occurs primarily in infants and young children. ${ }^{[28]}$ Also, MIS-C differs from acute COVID-19 in children, which is typically more severe in infants and children with underlying comorbidities. ${ }^{[29]}$ Based on the reports from the United Kingdom, Italy and USA, there seems to be a three- to four-week lag between COVID-19 peak and MIS-C cases, which roughly corresponds with the development of acquired immunity, suggesting that MIS-C represents a postinfectious complication rather than acute illness per se. ${ }^{[29]}$

In reports available up to date, the presenting symptom was fever lasting two to five days with prominent gastrointestinal symptoms (abdominal pain, vomiting, diarrhoea - even mimicking appendicitis) and in some children vasodilatory/distributive shock develops, refractory to volume resuscitation, requiring vasopressors and often mechanical hemodynamic support. ${ }^{[30,31]}$ Pulmonary involvement was not a prominent feature and respiratory symptoms such as tachypnoea, hypoxemia, etc., when present, occurred due to the shock. ${ }^{[31]}$ The most common laboratory findings were lymphocytopenia with neutrophilia, mild anaemia and thrombocytopenia, elevated inflammatory markers (C-reactive protein (CRP), erythrocyte sedimentation rate, $\mathrm{D}$-dimer, fibrinogen, ferritin, procalcitonin (PCT), and interleukin-6), elevated cardiac markers such as troponin and brain natriuretic peptide (BNP) or N-terminal prohormone of BNP (NT-proBNP), hypoalbuminemia, mildly elevated liver enzymes, elevated lactate dehydrogenase and hypertriglyceridemia. ${ }^{[32]}$ Echocardiography may reveal depressed left ventricle function and coronary arteries abnormalities, such as dilation or aneurysm, mitral valve regurgitation, and 
pericardial effusion, but the risk of cardiac involvement seems to be much lower than initial reports suggested. ${ }^{[33]}$ Many patients had normal findings on chest radiographs and CT scans. Some had small pleural effusions, patchy consolidations or ground-glass opacities. Abdominal imaging revealed ascites, terminal ileitis, mesenteric adenopathy and pericholecystic oedema.

It is becoming clear that the disease spectrum ranges from mild to severe. ${ }^{[29,34]}$ There are COVID-19 cases without an exaggerated immune response (no or only mild symptoms), COVID-19-associated febrile inflammatory state (persistent fevers, mild symptoms, elevated inflammatory markers, but no signs of multisystem involvement), COVID-19-associated KD (children meet criteria for complete or incomplete KD without multisystem involvement and shock) and COVID-19-associated MIS-C (more severe presentation, with multisystem involvement, markedly elevated inflammatory markers and development of shock with prominent cardiac involvement and gastrointestinal symptoms). It is still unclear how common each presentation is, as well as what are the risk factors for progression to more severe form of disease.

The case definition of MIS-C differs slightly between $\mathrm{CDC}$ and $\mathrm{WHO}-\mathrm{CDC}$ requires that symptoms are so severe that hospitalization is indicated, includes older age ( $<21$ y for CDC, $<19$ for WHO) and shorter duration of fever (more than 1 and 3 days respectively). Both definitions include elevated inflammation markers, evidence of SARS-CoV-2 infection, no other plausible diagnosis and evidence of at least two organ system involvement. ${ }^{[35]}$ All patients with suspected MIS-C should be tested for SARS-CoV-2, with both PCR and serology, since most children have positive serology with negative PCR. Testing for other possible causes should be performed because the diagnosis of MIS-C can be made only upon excluding other possible causes (such as sepsis, $\mathrm{KD}$, toxic shock syndrome, HLH, appendicitis, SLE etc.). Most patients require multidisciplinary care and those presenting with shock should be admitted to ICU and resuscitated according to the standard protocols. ${ }^{[36]}$

It is appropriate to start empirical antibiotic therapy for children with multisystem involvement and shock. The patients with criteria for $\mathrm{KD}$ should receive standard treatment, as well as those with myocardial dysfunction, who should be treated by cardiologist. Prognosis for MIS-C is still uncertain, given that it is a new clinical entity and our understanding is still evolving. However, most children did survive, with at least eight deaths out of 360 cases reported by three large case series. ${ }^{[28,37]}$

\section{Imaging}

Chest CT imaging plays a critical role in the surveillance and diagnosis of COVID-19 pneumonia with a higher sensitivity than chest X-ray which cannot exclude pulmonary lesions in patients with mild or no symptoms. ${ }^{[38-40]}$ Several reports found lung abnormalities on CT scan in asymptomatic children. ${ }^{[41,42]}$ However, since the extent of radiologic changes does not correlate with disease severity, CT scan should not be routinely done in children with COVID- 19 .

$\mathrm{Ma} \mathrm{H}$ et al. reported that among 43 paediatric patients, $67 \%$ of them had ground-glass opacity, 37\% local patchy shadowing, $21 \%$ local bilateral patchy shadowing and $65 \%$ of them had lesions located in the lower lobe. The subpleural lesions were present in $95 \% \cdot{ }^{[43]}$ Chinese authors also report ground-glass opacities as the most common manifestation, present in $60 \%$. In this study, consolidations with surrounding halo sign accounted for up to 50\% cases suggesting that they should be considered typical signs in paediatric patients. ${ }^{[40]}$

\section{Laboratory Findings and Diagnosis}

The laboratory findings are not specific. White blood cell count is usually normal (69.6\%) but can also be increased or decreased (15.2\% each). In $89.6 \%$ of the findings, the neutrophil counts were normal. ${ }^{[44]}$ The lymphocyte count can be normal, increased, which is described in $8 \%$ but also decreased, which is described in $3.5 \%-40 \% .{ }^{[42,43,45]}$ Lymphocytopenia rates are substantially lower than reported in adults. ${ }^{[46]}$ Some studies suggest that lymphopenia correlates with the infection severity (especially in adults). ${ }^{[14,47]}$ Lymphopenia may be absent in very young children due to the relative immaturity of their immune system and different immune response. ${ }^{[48,49]}$ In both SARS and MERS, lymphopenia was a predominant feature. [50,51] The underlying mechanism for SARS-CoV and MERS-CoV-induced lymphopenia could be distinct. A study by Chu et al. showed that MERS-CoV could directly infect $\mathrm{T}$ cells and induce apoptosis while lymphopenia during SARS-CoV might be due to different causes. ${ }^{[50]}$ Thrombocytopenia was described in $14 \%$ and thrombocytosisin $4 \% \cdot{ }^{[43]}$

The inflammatory markers CRP and PCT are rarely elevated - in up to $20 \%$ and $10.6 \%$ of the cases, respectively. ${ }^{[43,44]}$ PCT $>0.5 \mathrm{ng} / \mathrm{mL}$ indicates co-infection with bacteria in adults, but children with COVID-19 have more often elevated PCT than adult patients. ${ }^{[40]}$ Elevated leukocytes, neutrophil counts, CRP and PCT levels have been observed in cases of unfavourable progression in adults. ${ }^{[52]}$ Elevation of liver enzymes, 
muscle enzymes, myoglobin and increased level of D-dimer can be seen in severe cases. ${ }^{[14]}$

WHO divides COVID-19 cases into suspected, probable and confirmed. The latter is defined as a person with laboratory confirmation of SARS-CoV-2 infection, irrespective of clinical signs and symptoms. According to the American Academy of Paediatrics (AAP), children should be tested if symptomatic, in close contact with a positive person and prior to elective surgery. If children experience respiratory symptoms, testing for other respiratory viruses should also be considered due to a high level of co-infection. ${ }^{[53]}$

\section{Pregnancy}

The asymptomatic SARS-CoV-2 infection was detected in up to $90 \%$ of pregnant women where universal screening was performed. Rates of severe and critical disease are similar to those in the general population. Vertical transmission is possible but the precise time of infection was unclear (in utero, intrapartum or postpartum). Further investigations are needed in order to evaluate the risk of adverse outcomes and congenital syndromes. ${ }^{[54]}$

\section{Breastfeeding}

Current data suggest that SARS-CoV-2 is not transmitted via breastmilk. The mothers should be encouraged to breastfeed since breastfeeding benefits outweigh possible risks. The mothers and the infants should be cared for together and if a mother is too ill to breastfeed, milk should be given to her infant by a healthy individual. ${ }^{[55]}$

\section{Treatment}

Supportive care is recommended by various national committees and includes general treatment, symptomatic therapy, oxygen therapy, respiratory, fluid and electrolyte support.

Among antipyretics, acetaminophen is the preferred antipyretic agent and, if needed, non-steroidal anti-inflammatory drugs (NSAIDs) should be used in the lowest effective dose possible. ${ }^{[56-58]}$ Long-term NSAID therapy should be discontinued only in case of severe adverse reactions (e.g. gastrointestinal bleeding, renal injury). ${ }^{[7]}$

Antiviral therapy should be reserved for children with severe acute respiratory syndrome due to SARSCoV-2 infection. The multicentre interim guidance suggest that antiviral therapy should be considered on a case-by-case basis and, if possible, occur in the context of a clinical trial. ${ }^{[59,60]}$ Remdesivir is the only antiviral agent that showed beneficial effects in adult patients with COVID-19 while data in children are lacking. ${ }^{[7]}$ FDA and EMA have endorsed remdesivir for the treatment of COVID-19 in adults and children older than 12 years of age. Hydroxychloroquine is not recommended due to serious adverse effects, as well as lopinavir-ritonavir due to lack of efficacy and inappropriate pharmacodynamics. ${ }^{[61,62]}$

According to preliminary data collected in Randomised Evaluation of COVID-19 Therapy (RE-COVERY) trial, COVID-19 Treatment Guidelines Panel recommends using dexamethasone in adults who require supplemental oxygen or ventilatory support. Paediatric patients continue to be recruited in the paediatric component of the Recovery Trial. The effectiveness and safety of corticosteroids for COVID-19 treatment in children has not yet been studied. Dexamethasone may be beneficial in paediatric patients with COVID-19 who require ventilatory support while corticosteroids usage in other patients should be estimated on a case-by-case basis. ${ }^{[57]}$

Tocilizumab, a monoclonal antibody targeting IL-6 receptor binding sites, contributed to reduced mortality in adults with severe COVID-19. ${ }^{[63,64]}$

Tocilizumab is not recommended in the treatment of COVID-19 in children, except in a context of a clinical trial. ${ }^{[65]}$

\section{Vaccination}

Among all available COVID-19 vaccines, to date only Pfizer-BioNTech vaccine is authorized for usage in children older than 12 years by the FDA. ${ }^{[66]}$

\section{Conclusion}

Although almost a year has passed since the beginning of the pandemic, we are still lacking data regarding COVID-19 in children, especially regarding the role of children in SARS-CoV-2 transmission and treatment. Our knowledge to date suggests that children experience milder disease (except children with coexisting conditions) and are rarely index cases.

\section{REFERENCES}

${ }^{[1]}$ Hua W, Xiaofeng L, Zhenqiang B, Jun R, Ban W, Liming L. Consideration on the strategies during epidemic stage changing from emergency response to continuous prevention and control. Chinese J Endem. 2020;41(2):297-300.

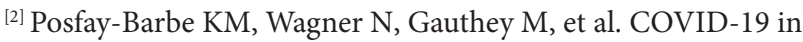
Children and the Dynamics of Infection in Families. Pediatrics 2020;146(2):e20201576.

${ }^{[3]}$ World Health Organization. Report of the WHO-China Joint Mission on Coronavirus Disease 2019 (COVID-19). Geneva: WHO; 2020. Available from: https://www.who.int/publications/i/item/report-of-the-who-china-joint-mission-on-coronavirus-disease-2019-(covid-19) 
${ }^{[4]}$ Cai J, Xu J, Lin D, et al. A Case Series of children with 2019 novel coronavirus infection: clinical and epidemiological features. Clin Infect Dis. 2020;71(6):1547-51.

${ }^{[5]}$ Fang F, Luo XP. Facing the pandemic of 2019 novel coronavirus infections: the pediatric perspectives. Zhonghua Er Ke Za Zhi. 2020;58(2):81-5.

${ }^{[6]}$ Buonsenso D, Zampino G, Valentini P. Novel Coronavirus Disease 2019 Infection in Children: The Dark Side of a Worldwide Outbreak. Front Pediatr. 2020;8:215.

${ }^{[7]}$ McIntosh K. Coronaviruses. In: UpToDate, Post TW (ed), UpToDate, Waltham, MA. (Accessed June 11, 2020) Available from: https://www.uptodate.com/contents/coronaviruses? search $=$ coronaviruses\&source $=$ search_result\&selectedTitle $=1 \sim 48 \&$ usage_type $=$ default\&display_rank $=1$

${ }^{[8]}$ Paules CI, Marston HD, Fauci AS. Coronavirus Infections-More Than Just the Common Cold. JAMA. 2020;323(8):707-8.

${ }^{[9]}$ Chonmaitree T, Trujillo R, Jennings K, et al. Acute otitis media and other complications of viral respiratory infection. Pediatrics. 2016;137(4):e20153555.

${ }^{[10]}$ Zhu N, Zhang D, Wang W, et al. A novel coronavirus from patients with pneumonia in China, 2019. N Engl J Med. 2020;382(8):727-33.

${ }^{[11]}$ Li Q, Guan X, Wu P, et al. Early Transmission Dynamics in Wuhan, China, of Novel Coronavirus-Infected Pneumonia. N Engl J Med. 2020;382(13):1199-207.

${ }^{[12]}$ Morawska L, Milton DK. It Is Time to Address Airborne Transmission of Coronavirus Disease 2019 (COVID-19). Clin Infect Dis. 2020;71(9):2311-3.

${ }^{[13]} \mathrm{Xu}$ Y, Li X, Zhu B, et al. Characteristics of pediatric SARS$\mathrm{CoV}-2$ infection and potential evidence for persistent fecal viral shedding. Nat Med. 2020;26(4):502-5.

${ }^{[14]}$ Chen ZM, Fu JF, Shu Q, et al. Diagnosis and treatment recommendations for pediatric respiratory infection caused by the 2019 novel coronavirus. World J Pediatr. 2020;16(3):240-6.

${ }^{[15]}$ Zou L, Ruan F, Huang M, et al. SARS-CoV-2 viral load in upper respiratory specimens of infected patients. N Engl J Med. 2020;382(12):1177-9.

${ }^{[16]}$ Contejean A, Leporrier J, Canouï E, et al. Comparing Dynamics and Determinants of Severe Acute Respiratory Syndrome Coronavirus 2 Transmissions Among Healthcare Workers of Adult and Pediatric Settings in Central Paris. Clin Infect Dis. 2021;72(2):257-64.

${ }^{[17]}$ Zhu Y, Bloxham C, Hulme K, et al. A meta-analysis on the role of children in SARS-CoV-2 in household transmission clusters. Clin Infect Dis. 2020 Dec 6:ciaa1825.

${ }^{[18]}$ Park YJ, Choe YJ, Park O, et al. Contact Tracing during Coronavirus Disease Outbreak, South Korea, 2020. Emerg Infect Dis. 2020;26(10):2465-68.

${ }^{[19]}$ Stein-Zamir C, Abramson N, Shoob H, et al. A large COVID-19 outbreak in a high school 10 days after schools' reopening, Israel, May 2020. Euro Surveill. 2020;25(29):2001352.

${ }^{[20]}$ European Centre for Disease Prevention and Control. COVID-19 in children and the role of school settings in transmission - first update. Stockholm: ECDC; 2020. Available from: https://www.ecdc.europa.eu/en/publications-data/childrenand-school-settings-covid-19-transmission

${ }^{[21]}$ Eastin C, Eastin T. Epidemiological characteristics of 2143 pediatric patients with 2019 coronavirus disease in China: Dong Y, Mo X, Hu Y, et al. Pediatrics. 2020; J Emerg Med. 2020;58(4):712-3.
${ }^{[22]}$ Song X, Delaney M, Shah RK, Campos JM, Wessel DL, DeBiasi RL. Comparison of Clinical Features of COVID-19 vs Seasonal Influenza A and B in US Children. JAMA Netw Open. 2020;3(9):e2020495.

${ }^{[23]}$ Götzinger F, Santiago-García B, Noguera-Julián A, et al. COVID-19 in children and adolescents in Europe: a multinational, multicentre cohort study. Lancet Child Adolesc Health. 2020;4(9):653-661.

${ }^{[24]}$ Ogimi C, Englund JA, Bradford MC, Qin X, Boeckh M, Waghmare A. Characteristics and outcomes of coronavirus infection in children: The role of viral factors and an immunocompromised state. J Pediatric Infect Dis Soc. 2019;8(1):21-8.

${ }^{[25]}$ Haehner A, Draf J, Dräger S, de With K, Hummel T. Predictive Value of Sudden Olfactory Loss in the Diagnosis of COVID-19. ORL J Otorhinolaryngol Relat Spec. 2020;82(4):175-180.

${ }^{[26]}$ Mak PQ, Chung KS, Wong JSC, Shek CC, Kwan MYW. Anosmia and Ageusia: Not an Uncommon Presentation of COVID-19 Infection in Children and Adolescents. Pediatr Infect Dis J. 2020;39(8):E199-200.

${ }^{[27]}$ Qiu C, Cui C, Hautefort C, et al. Olfactory and Gustatory Dysfunction as an Early Identifier of COVID-19 in Adults and Children: An International Multicenter Study. Otolaryngol Neck Surg. 2020;2019:019459982093437.

${ }^{[28]}$ Riphagen S, Gomez X, Gonzalez-Martinez C, Wilkinson N, Theocharis P. Hyperinflammatory shock in children during COVID-19 pandemic. Lancet. 2020;395(10237):1607-8.

${ }^{[29]}$ Whittaker E, Bamford A, Kenny J, et al. Clinical Characteristics of 58 Children with a Pediatric Inflammatory Multisystem Syndrome Temporally Associated with SARS-CoV-2. JAMA. 2020;324(3):259-69.

${ }^{[30]}$ Tullie L, Ford K, Bisharat M, et al. Gastrointestinal features in children with COVID-19: an observation of varied presentation in eight children. Lancet Child Adolesc Health. 2020;4(7):e19-e20.

${ }^{[31]}$ Feldstein LR, Rose EB, Horwitz SM, et al. Multisystem Inflammatory Syndrome in U.S. Children and Adolescents. N Engl J Med. 2020;383(4):334-46.

${ }^{[32]}$ Davies P, Evans C, Kanthimathinathan HK, et al. Intensive care admissions of children with paediatric inflammatory multisystem syndrome temporally associated with SARS-CoV-2 (PIMS-TS) in the UK: a multicentre observational study. Lancet Child Adolesc Health. 2020;4(9):669-77.

${ }^{[33]}$ Belhadjer Z, Méot M, Bajolle F, et al. Acute heart failure in multisystem inflammatory syndrome in children (MIS-C) in the context of global SARS-CoV-2 pandemic. Circulation. 2020;142(5):429-436.

${ }^{[34]}$ Toubiana J, Poirault C, Corsia A, et al. Kawasaki-like multisystem inflammatory syndrome in children during the covid-19 pandemic in Paris, France: prospective observational study. BMJ. 2020;369:m2094.

${ }^{[35]}$ World Health Organization. Multisystem inflammatory syndrome in children and adolescents with COVID-19 [Internet]. Scientif Brief. 15 May 2020. Available from: https://www.who. int/images/default-source/health-topics/coronavirus/mis-scientificbrief-thumbnail.tmb-479v.png?sfvrsn=78fc8aac_1

${ }^{[36]}$ Henderson LA, Canna SW, Friedman KG, et al. American College of Rheumatology Clinical Guidance for Multisystem Inflammatory Syndrome in Children Associated With SARSCoV-2 and Hyperinflammation in Pediatric COVID-19: Version 1. Arthritis Rheumatol. 2020;72(11):1791-805. 
${ }^{[37]}$ Godfred-Cato S, Bryant B, Leung J, et al. COVID-19-Associated Multisystem Inflammatory Syndrome in Children - United States, March-July 2020. MMWR Morb Mortal Wkly Rep. 2020;69(32):1074-80.

${ }^{[38]}$ Yang W, Sirajuddin A, Zhang X, et al. The role of imaging in 2019 novel coronavirus pneumonia (COVID-19). Eur Radiol. 2020;30(9):4874-82.

${ }^{[39]}$ Liu H, Liu F, Li J, Zhang T, Wang D, Lan W. Clinical and CT imaging features of the COVID-19 pneumonia: Focus on pregnant women and children. J Infect. 2020;80(5):e7-13.

${ }^{[40]}$ Xia W, Shao J, Guo Y, Peng X, Li Z, Hu D. Clinical and CT features in pediatric patients with COVID-19 infection: Different points from adults. Pediatr Pulmonol. 2020;55(5):1169-74.

${ }^{[41]}$ Chan JFW, Yuan S, Kok KH, et al. A familial cluster of pneumonia associated with the 2019 novel coronavirus indicating person-to-person transmission: a study of a family cluster. Lancet. 2020;395(10223):514-23.

${ }^{[42]} \mathrm{Lu} \mathrm{X}$, Zhang L, Du H, et al. SARS-CoV-2 Infection in Children. N Engl J Med. 2020;382(17):1663-65.

${ }^{[43]} \mathrm{Ma} \mathrm{H}, \mathrm{Hu}$ J, Tian J, et al. A single-center, retrospective study of COVID-19 features in children: a descriptive investigation. BMC Med. 2020;18(1):123.

${ }^{[44]}$ Henry BM, Lippi G, Plebani M. Laboratory abnormalities in children with novel coronavirus disease 2019. Clin Chem Lab Med. 2020;58(7):1135-8.

${ }^{[45]} \mathrm{Li}$ Y, Guo FF, Cao Y, Li LF, Guo YJ. Insight into COVID-2019 for pediatricians. Pediatr Pulmonol. 2020;55(5):E1-4.

${ }^{[46]}$ Guan W, Ni Z, Hu Y, et al. Clinical Characteristics of Coronavirus Disease 2019 in China. N Engl J Med. 2020;382(18):1708-20.

${ }^{[47]}$ Yang X, Yu Y, Xu J, et al. Clinical course and outcomes of critically ill patients with SARS-CoV-2 pneumonia in Wuhan, China: a single-centered, retrospective, observational study. Lancet Respir Med. 2020;8(5):475-81.

${ }^{[48]}$ Klein SL, Flanagan KL. Sex differences in immune responses. Nat Rev Immunol. 2016;16(10):626-38.

${ }^{[49]}$ Chen F, Liu ZS, Zhang FR, et al. First case of severe childhood novel coronavirus pneumonia in China. Zhonghua Er Ke Za Zhi. 2020;58(3):179-82.

${ }^{[50]}$ Chu H, Zhou J, Wong BHY, et al. Middle East Respiratory Syndrome Coronavirus Efficiently Infects Human Primary T Lymphocytes and Activates the Extrinsic and Intrinsic Apoptosis Pathways. J Infect Dis. 2016;213(6):904-14.

${ }^{[51]} \mathrm{He}$ Z, Zhao C, Dong Q, et al. Effects of severe acute respiratory syndrome (SARS) coronavirus infection on peripheral blood lymphocytes and their subsets. Int J Infect Dis. 2005;9(6):323-30.

${ }^{[52]}$ Lippi G, Plebani M. Laboratory abnormalities in patients with COVID-2019 infection. Clin Chem Lab Med. 2020;58(7):1131-4.

${ }^{[53]}$ American Academy of Pediatrics. Coronaviruses, Including SARS-CoV-2 and MERS-CoV. In: eds. Red Book: 2021-2024 Report of the Committee on Infectious Diseases. American Academy of Pediatrics; 2021; 280-285
${ }^{\text {[54] }}$ Pettirosso E, Giles M, Cole S, Rees M. COVID-19 and pregnancy: a review of clinical characteristics, obstetric outcomes and vertical transmission. Aust New Zeal J Obstet Gynaecol. 2020;60(5):640-59.

${ }^{[55]}$ Lubbe W, Botha E, Niela-Vilen H, Reimers P. Breastfeeding during the COVID-19 pandemic - a literature review for clinical practice. Int Breastfeed J. 2020;15(1):1-9.

${ }^{[56]}$ European Medicines Agency. EMA gives advice on the use of non-steroidal anti-inflammatories for COVID-19 [Internet]. [Accessed May 18, 2020]. Available from: https://www.ema. europa.eu/en/news/ema-gives-advice-use-non-steroidal-anti-inflammatories-covid-19

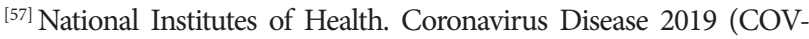
ID-19) Treatment Guidelines [Internet]. [Accessed May 18, 2020]. Available from: https://covid19treatmentguidelines.nih.gov/

${ }^{[58]}$ World Health Organization. The use of non-steroidal anti-inflammatory drugs (NSAIDs) in patients with COVID-19 [Internet]. [Accessed May 18, 2020]. Available from: https://www. who.int/publications-detail/the-use-of-non-steroidal-anti-inflammatory-drugs-(nsaids)-in-patients-with-covid-19

${ }^{[59]}$ Campbell JI, Ocwieja KE, Nakamura MM. A call for pediatric Covid-19 clinical trials. Pediatrics. 2020;146(2):e20201081.

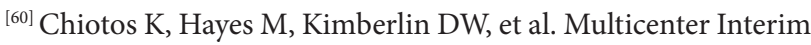
Guidance on Use of Antivirals for Children With Coronavirus Disease 2019/Severe Acute Respiratory Syndrome Coronavirus 2. J Pediatric Infect Dis Soc. 2021;10(1):34-48.

${ }^{\left[{ }^{61]}\right.}$ Mercuro NJ, Yen CF, Shim DJ, et al. Risk of QT Interval Prolongation Associated With Use of Hydroxychloroquine With or Without Concomitant Azithromycin Among Hospitalized Patients Testing Positive for Coronavirus Disease 2019 (COVID-19). JAMA Cardiol. 2020;5(9):1036-41.

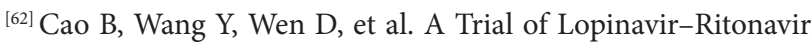
in Adults Hospitalized with Severe Covid-19. N Engl J Med. 2020;382(19):1787-99.

${ }^{[63]}$ Berardicurti O, Ruscitti P, Ursini F, et al. Mortality in tocilizumab-treated patients with COVID-19: a systematic review and meta-analysis. Clin Exp Rheumatol. 2020;38(6):1247-54.

${ }^{[64]}$ Gokhale Y, Mehta R, Kulkarni U, et al. Tocilizumab improves survival in severe COVID-19 pneumonia with persistent hypoxia: a retrospective cohort study with follow-up from Mumbai, India. BMC Infect Dis. 2021;21(1):1-10.

${ }^{\left[{ }^{65]}\right.}$ Dulek DE, Fuhlbrigge RC, Tribble AC, et al. Multidisciplinary Guidance Regarding the Use of Immunomodulatory Therapies for Acute Coronavirus Disease 2019 in Pediatric Patients. J Pediatric Infect Dis Soc. 2020;9(6):716-37.

${ }^{\left[{ }^{66]}\right.}$ FDA. Coronavirus (COVID-19) Update: FDA Authorizes Pfizer-BioNTech COVID-19 Vaccine for Emergency Use in Adolescents in Another Important Action in Fight Against Pandemic [Internet]. [Accessed May 10, 2021]. Available from: https://www.fda.gov/news-events/press-announcements/ coronavirus-covid-19-update-fda-authorizes-pfizer-biontech-covid-19-vaccine-emergency-use. 